\section{Copper-treated Plug Flats Influence Root Growth and Flowering of Bedding Plants}

\author{
A.M. Armitage and P.M. Gross \\ Department of Horticulture, University of Georgia, Athens, GA 30602
}

Additional index words. copper hydroxide, Impatiens, Petunia, Pelargonium, geranium

\begin{abstract}
A copper hydroxide formulation $(0 \%, 3.5 \%, 7 \%, 11 \% \mathrm{Cu})$ was applied to plug trays before sowing seeds of Impatiens $\times$ hybrida $L$. 'Accent Red', Pelargonium $\times$ hortorum Bailey 'Scarlet Elite', and Petunia $\times$ hybrida Hort.Vilm.-Andr. 'Ultra White' to investigate the influence of the formulations on ease of transplant, root growth, and shoot growth. These factors also were investigated in Cu-treated seedling plugs held past optimal transplanting stage. Root spiraling and seedling height at transplant were reduced for all taxa grown in $\mathrm{Cu}$-treated trays, regardless of concentration, compared to seedlings from nontreated trays. Root weight and shoot weight responses to $\mathrm{Cu}$ treatments at transplant and at flowering varied among taxa. Mature heights of all taxa were unaffected by $\mathrm{Cu}$ treatment; however, flowering date was delayed for impatiens and geraniums transplanted at optimal time from $\mathrm{Cu}$-treated trays. In general, petunias displayed little response to $\mathrm{Cu}$ treatment. Root spiraling was reduced and plugs were removed more easily from $\mathrm{Cu}$-treated than from control trays stored for 2 weeks in the greenhouse, but flowering time was delayed for 12 days for impatiens and petunias and 21 days for geraniums, regardless of $\mathrm{Cu}$ concentration.
\end{abstract}

Root-growth inhibition by $\mathrm{Cu}$ solutions was reported more than 40 years ago (Stinson and Keyes, 1953), but little commercial interest was demonstrated until the late 1970s, when $\mathrm{Cu}$-coated growing containers showed benefits to the forestry industry. The $\mathrm{Cu}$ compounds prevented conifer root tips from clustering at drainage holes, resulting in better stability when plants were transplanted (Burdett, 1978; Burdett and Martin, 1982; McDonald et al., 1984). Additionally, work with numerous woody landscape plants, particularly deciduous species, showed modification of root growth, with improved root morphology and distribution in the containers (Arnold and Struve, 1989; McDonald et al. 1984; Ruehle, 1985; Ruter, 1994; Struve and Rhodus, 1990, 1994). Copper-containing compounds applied to the interior of containers generally inhibited root elongation, prevented root spiraling in containers, increased root branching, and tended to reduce the root : shoot ratio in most taxa studied (Struve and Rhodus, 1990)

Copper-treated containers are now an integral part of innovative production systems in many woody plant nurseries (Struve et al.,

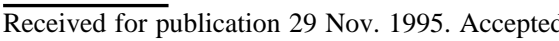
for publication 20 June 1996. Thanks to Meg Green for her assistance and Mark Crawford of Griffin Corp. for his contributions. Use of trade names does not imply endorsement of the products named nor criticism of similar ones not named. The cost of publishing this paper was defrayed in part by the payment of page charges. Under postal regulations, this paper therefore must be hereby marked advertisement solely to indicate this fact.
}

1987). Recently, the influence of $\mathrm{Cu}$, in the form of copper hydroxide $\left[\mathrm{Cu}(\mathrm{OH})_{2}\right]$, applied to the interior of containers in which herbaceous species were grown was investigated (Arnold et al., 1993; Case and Arnold, 1992; Krieg and Witte, 1993). The influence of a 7\% $\mathrm{Cu}(\mathrm{OH})_{2}$ formulation on flowering of bedding plants in 8-cm treated pots was studied in the greenhouse and in the field (Arnold et al., 1993). They reported increased vegetative growth with Pelargonium and increased flower counts with Impatiens grown in the greenhouse. To our knowledge, studies to determine the influence of applying a $\mathrm{Cu}$ treatment to plug containers used in modern bedding plant production have not been reported. A compound that restricts root spiraling has potential benefit for plug-grown seedlings if easier removal of plugs from trays and rapid root growth in the final container can be demonstrated. Additionally, due to sales limitations, scheduling problems, or labor shortages, seedling plugs are often held on the greenhouse bench of the plug grower or finisher past the optimal time for transplanting. This additional time in the greenhouse could increase root spiraling and binding of roots to the side of the plug cavity, which, in turn, could reduce the efficiency of transplanting equipment, cause root damage upon transplanting, and delay subsequent root growth. However, if roots are forced away from the sides and into the middle of the cavity without reducing growth or quality of the plugs, then fewer problems with root restriction of stored transplants will occur.

Our objectives were to determine the influence of $\mathrm{Cu}(\mathrm{OH})_{2}$ on plug production and subsequent flowering of the mature plant in a 10$\mathrm{cm}(450-\mathrm{mL})$ container and to examine growth and flowering of plugs grown in $\mathrm{Cu}$-treated trays held for 2 weeks after transplantable size.
Plug flats were treated with latex paint formulations containing $0,50,100,150 \mathrm{mg}$ $\mathrm{Cu}(\mathrm{OH})_{2} / \mathrm{L}$ (Griffin Corp., Valdosta, Ga.); actual rates were $3.5 \%, 7 \%$, and $11 \% \mathrm{Cu}$. Concentrations were listed by Griffin as $4 \%$, $8 \%$, and $12 \% \mathrm{Cu}$ based on actual technical $\mathrm{Cu}(\mathrm{OH})_{2}$ added, which is not $100 \%$ pure. The formulations were applied without dilution with an airless paint sprayer to provide an even coating $0.08 \mathrm{~mm}$ thick containing $14 \mathrm{mg}$ coat$\mathrm{ing} / \mathrm{cm}^{2}$. Seeds of petunia, impatiens, and geranium were obtained from Goldsmith Seed Co. (Gilroy, Calif.) and sown in Fafard Peat/ Lite mix (Anderson, S.C.) to separate 406-cell plug flats $(0.00048 \mathrm{~L} /$ cell $)$ treated with $\mathrm{Cu}(\mathrm{OH})_{2}$, as noted, on 6 June 1993. Seeds were germinated, each tray thinned to 100 seedlings in a block with no empty cells between seedlings, and trays were placed in glass greenhouses with liquid shade (a dilution of white latex paint of $\approx 15$ parts water : 1 part paint applied with rollers to the outside of glasshouses) at the Univ. of Georgia. Neither supplemental lighting nor photoperiod control was used. Day/night temperatures varied with ambient temperatures, but setpoints were 23 ${ }^{\circ} \mathrm{C}$ day $/ 16^{\circ} \mathrm{C}$ night. Seedlings were fertilized with $\mathrm{N}$ at $150 \mathrm{mg} \cdot \mathrm{L}^{-1}(15 \mathrm{~N}-9.9 \mathrm{P}-14.1 \mathrm{~K})$ at each daily irrigation. To reduce soluble salt buildup, plants received only water every fifth irrigation.

Transplantable stage was defined as the time when adjacent seedling leaves overlapped and an intact root ball was evident when plugs were lifted from their cavities. At this time, 10 seedlings of each treatment (for each species) were randomly selected and transplanted to $10-\mathrm{cm}(450-\mathrm{mL})$ round green pots, and 10 seedlings were used for measurement, as noted below. Plug flats remained in the greenhouse for an additional 2 weeks, then 10 seedlings were transplanted and 10 were measured. At each transplant date, seedling height, root dry weight (RDW), and shoot dry weight (SDW) were measured. When each potted plant reached anthesis, final height, shoot dry weight, and time to flowering were measured. The experiment was repeated in its entirety with seeds sown on 9 Aug. and transplanted on 19 Sept. (petunias, impatiens) and 25 Sept. (geraniums) and again 2 weeks later. Data from the two experiments were combined. Data within each transplant period were subjected to analysis of variance $(P \leq 0.05)$ and trend analysis to determine response due to $\mathrm{Cu}$ treatment.

\section{Results}

General observations. Petunia, impatiens, and geranium reached transplantable stage after 43,49 , and 52 days, respectively. Roots of control plants for all taxa exhibited typical spiraling within the container, while those of plants from $\mathrm{Cu}$-treated trays did not. Roots of nontreated plants were more numerous at the perimeter of the root plug (Fig. 1). This condition prevailed for plugs transplanted at the transplantable stage and for those held an additional 2 weeks. Roots of seedlings that 


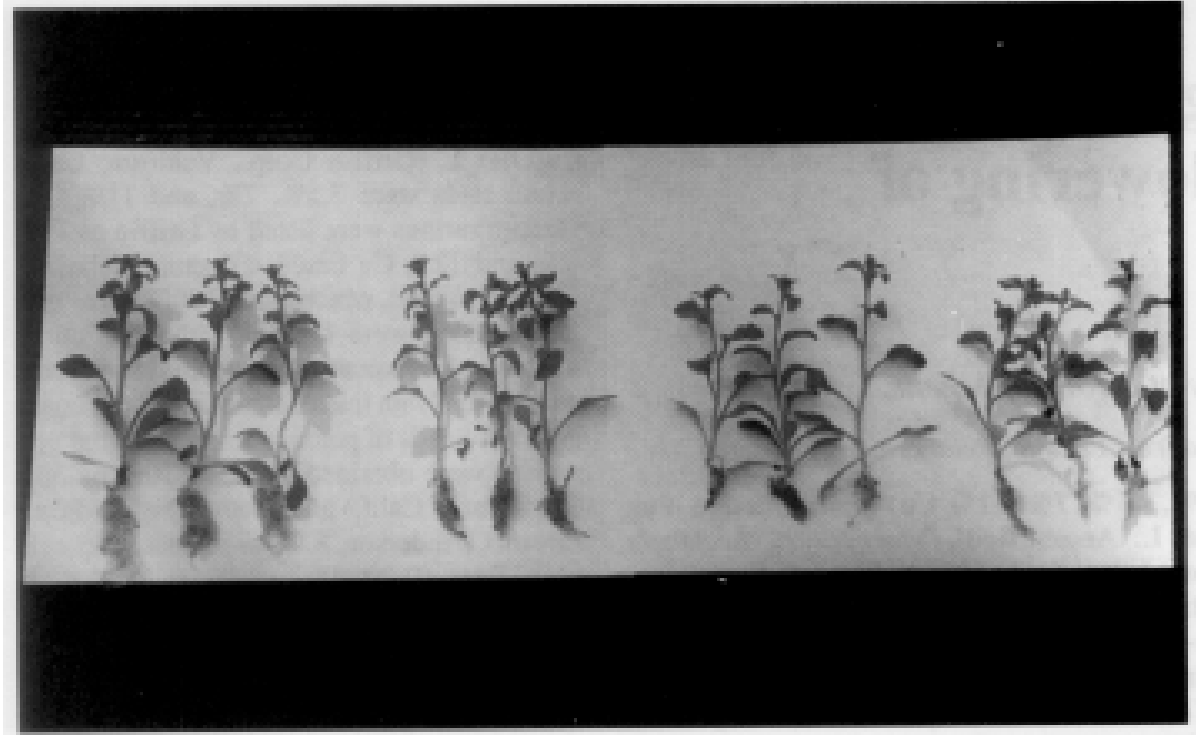

Fig. 1. Effect of $\mathrm{Cu}(\mathrm{OH})_{2}$ on root growth of petunia in plug flats treated with $0 \%, 3.5 \%, 7 \%$, or $11 \% \mathrm{Cu}$.

contacted treated surfaces exhibited typical $\mathrm{Cu}$ toxicity symptoms, confined mainly to apical tips of the roots. Fewer roots appeared on the exterior of root plugs treated with $3.5 \%$ or $7 \% \mathrm{Cu}$, and plugs could be removed from plug trays intact. However, some root balls of plugs from trays treated with $11 \% \mathrm{Cu}$ were loose and poorly formed, resulting in poor plug integrity upon removal. In general, there was little difference in ease of removal of plugs from treated vs. nontreated trays at time of optimal transplanting. However, after 2 weeks of storage, plugs from trays treated with any concentration of $\mathrm{Cu}$ were more easily removed than those from nontreated trays.

Within a species, there were no differences among treatments in time to reach transplantable stage (data not shown). Anthesis was 9 to 23 days later in plants from stored plugs than in plants from those not stored. Inflorescence or flower count within a taxon was not affected by $\mathrm{Cu}$ (data not shown), and all plants appeared to flower normally, regardless of treatment.

\section{Response by species}

Impatiens 'Accent Red'. At transplant, seedlings exhibited a linear decrease in height, RDW, and SDW with increasing $\mathrm{Cu}$ concentrations (Table 1). Seedlings stored 2 weeks also displayed at transplant a linear decrease in height, RDW, and SDW with increasing $\mathrm{Cu}$ concentration; however, height differences among all treatments except the control were negligible from a practical standpoint. For both transplant stages, nonstored and stored, control seedlings were taller with more shoot and root growth at transplant than seedlings grown in $\mathrm{Cu}$-treated trays.

At flowering, no significant differences in plant height could be detected across $\mathrm{Cu}$ treatments within either stored or nonstored plants. Plants from plugs not stored exhibited a linear decrease in SDW with increasing Cu concentrations. Plants from stored plugs displayed a cubic response of SDW to Cu treatment; however, we interpreted this response as providing no physiological or practical information. Days to flower for nonstored plants increased linearly with increasing $\mathrm{Cu}$ concentration, with control plants flowering fastest. All stored plants flowered at about the same time. However, stored seedlings required an average of 12 additional days to reach anthesis compared to nonstored plants, regardless of $\mathrm{Cu}$ treatment.

Pelargonium 'Scarlet Elite'. At transplant, seedling height of nonstored plugs exhibited a quadratic trend across $\mathrm{Cu}$ concentrations, with control plants being the tallest (Table 2). Height of stored seedlings displayed a similar but linear trend. RDW of nonstored seedlings showed no trend across $\mathrm{Cu}$ concentrations, while RDW of stored seedlings decreased linearly. SDW decreased linearly as $\mathrm{Cu}$ con- centration increased for both nonstored and stored seedlings.

At flowering, no differences in height due to $\mathrm{Cu}$ concentration could be detected among plants from nonstored or stored plugs. SDW of both stored and nonstored plants showed no significant trends across $\mathrm{Cu}$ concentrations. However, within a storage treatment, control plants had higher mean SDWs than any $\mathrm{Cu}-$ treated plants. Days to flower for both stored and nonstored plants increased linearly with increasing $\mathrm{Cu}$ concentrations. Similar to impatiens, storage of seedlings led to additional time to flower $(\approx 21$ days), regardless of $\mathrm{Cu}$ treatment.

Petunia 'Ultra White'. At transplant, seedling height showed a quadratic response to $\mathrm{Cu}$ concentration, with seedlings from $3.5 \% \mathrm{Cu}$ trays being the shortest (Table 3). Seedling height of plugs stored 2 weeks displayed a decreasing linear trend as $\mathrm{Cu}$ concentration increased. RDW of nonstored seedlings was unaffected by $\mathrm{Cu}$ treatment, as was RDW of those stored 2 weeks. SDW of nonstored seedlings was unaffected by $\mathrm{Cu}$ treatment; however, SDW of seedlings stored 2 weeks displayed a decreasing linear trend across $\mathrm{Cu}$ treatments. However, the practical differences of SDW among all Cu treatments except control for stored seedlings were inconsequential.

At flowering, there were no height differences across $\mathrm{Cu}$ treatments within either stored or nonstored plants. SDW of stored and nonstored plants responded quadratically to $\mathrm{Cu}$ concentration, with the highest SDW (within a storage group) occurring in plants from $3.5 \% \mathrm{Cu}$ trays. Days to flower were not affected by $\mathrm{Cu}$ treatments for either stored or nonstored plants. Flowering was delayed by $\approx 12$ days for stored vs. nonstored plants, regardless of $\mathrm{Cu}$ treatment.

\section{Discussion}

Seedlings within each species grown in trays without $\mathrm{Cu}$ were always taller than those grown in any $\mathrm{Cu}$-treated tray (within either storage treatment). Svenson and Johnson (1992) showed significantly less elongation of Radermachera grown in $\mathrm{Cu}$-treated containers, but other work with $\mathrm{Cu}$ on herbaceous species did not result in shorter plants (Arnold et al., 1993; Case and Arnold, 1992). None of the previous work with herbaceous species was conducted with plug trays or with seedlings. Shorter seedlings are not a concern if subsequent growth and flowering are unaf-

Table 1. The influence of copper treatment of plug trays on seedling and flowering plant charactersitics of Impatiens 'Accent Red'.

\begin{tabular}{|c|c|c|c|c|c|c|c|c|c|c|c|c|}
\hline \multirow[b]{3}{*}{$\begin{array}{l}\mathrm{Cu} \text { concn } \\
(\%)\end{array}$} & \multicolumn{3}{|c|}{$\begin{array}{l}\text { At transplant } \\
\text { (plugs) }\end{array}$} & \multicolumn{3}{|c|}{$\begin{array}{l}\text { After } 2 \text { weeks } \\
\text { storage (plugs) }\end{array}$} & \multicolumn{3}{|c|}{$\begin{array}{l}\text { At flowering } \\
\text { (in pot) }\end{array}$} & \multicolumn{3}{|c|}{$\begin{array}{l}\text { At flowering (in pot) from } \\
\text { seedlings stored } 2 \text { weeks }\end{array}$} \\
\hline & \multirow[b]{2}{*}{$\begin{array}{c}\mathrm{Ht} \\
(\mathrm{cm})\end{array}$} & \multicolumn{2}{|c|}{ Dry wt $(\mathrm{g})$} & \multirow[b]{2}{*}{$\begin{array}{c}\mathrm{Ht} \\
(\mathrm{cm})\end{array}$} & \multicolumn{2}{|c|}{ Dry wt (g) } & \multirow[b]{2}{*}{$\begin{array}{l}\mathrm{Ht} \\
(\mathrm{cm})\end{array}$} & \multirow{2}{*}{$\begin{array}{c}\text { Shoot } \\
\text { dry wt } \\
(\mathrm{g})\end{array}$} & \multirow[b]{2}{*}{$\begin{array}{l}\text { Days to } \\
\text { flower }\end{array}$} & \multirow[b]{2}{*}{$\begin{array}{c}\mathrm{Ht} \\
(\mathrm{cm})\end{array}$} & \multirow{2}{*}{$\begin{array}{c}\text { Shoot } \\
\text { dry wt } \\
(\mathrm{g})\end{array}$} & \multirow[b]{2}{*}{$\begin{array}{r}\text { Days to } \\
\text { flower }\end{array}$} \\
\hline & & Root & Shoot & & Root & Shoot & & & & & & \\
\hline$\overline{0}$ & 8.1 & 0.21 & 1.26 & 15.5 & 0.29 & 2.78 & 13.4 & 2.66 & 72 & 14.0 & 3.33 & 84 \\
\hline 3.5 & 6.2 & 0.15 & 0.90 & 7.3 & 0.23 & 1.90 & 13.3 & 2.24 & 76 & 11.9 & 1.71 & 88 \\
\hline 7 & 4.7 & 0.12 & 0.78 & 7.4 & 0.20 & 1.73 & 12.8 & 2.21 & 78 & 13.5 & 2.68 & 90 \\
\hline 11 & 4.9 & 0.12 & 0.66 & 7.4 & 0.18 & 1.21 & 13.0 & 2.01 & 78 & 12.4 & 1.71 & 89 \\
\hline Trend analysis ${ }^{y}$ & $\mathrm{~L}$ & $\mathrm{~L}$ & $\mathrm{~L}$ & $\mathrm{~L}$ & $\mathrm{~L}$ & $\mathrm{~L}$ & NS & $\mathrm{L}$ & $\mathrm{L}$ & NS & $\mathrm{C}$ & NS \\
\hline
\end{tabular}

${ }^{\mathrm{z}}$ Values are means of 10 observations.

${ }^{\mathrm{y}}$ Nonsignificant (NS), linear (L), or cubic (C); significant at $P \leq 0.05$. 
Table 2. The influence of copper treatment of plug trays on seedling and flowering plant charactersitics of Pelargonium 'Scarlet Elite'.

\begin{tabular}{|c|c|c|c|c|c|c|c|c|c|c|c|c|}
\hline \multirow[b]{3}{*}{$\begin{array}{l}\mathrm{Cu} \text { concn } \\
(\%)\end{array}$} & \multicolumn{3}{|c|}{$\begin{array}{l}\text { At transplant } \\
\text { (plugs) }\end{array}$} & \multicolumn{3}{|c|}{$\begin{array}{l}\text { After } 2 \text { weeks } \\
\text { storage (plugs) }\end{array}$} & \multicolumn{3}{|c|}{$\begin{array}{l}\text { At flowering } \\
\text { (in pot) }\end{array}$} & \multicolumn{3}{|c|}{$\begin{array}{l}\text { At flowering (in pot) from } \\
\text { seedlings stored } 2 \text { weeks }\end{array}$} \\
\hline & \multirow[b]{2}{*}{$\begin{array}{c}\mathrm{Ht} \\
(\mathrm{cm})\end{array}$} & \multicolumn{2}{|c|}{ Dry wt $(\mathrm{g})$} & \multirow[b]{2}{*}{$\begin{array}{l}\mathrm{Ht} \\
(\mathrm{cm})\end{array}$} & \multicolumn{2}{|c|}{ Dry wt $(\mathrm{g})$} & \multirow[b]{2}{*}{$\begin{array}{l}\mathrm{Ht} \\
(\mathrm{cm})\end{array}$} & \multirow{2}{*}{$\begin{array}{c}\text { Shoot } \\
\text { dry wt } \\
\text { (g) }\end{array}$} & \multirow[b]{2}{*}{$\begin{array}{l}\text { Days to } \\
\text { flower }\end{array}$} & \multirow[b]{2}{*}{$\begin{array}{c}\mathrm{Ht} \\
(\mathrm{cm})\end{array}$} & \multirow{2}{*}{$\begin{array}{l}\text { Shoot } \\
\text { dry wt } \\
\text { (g) }\end{array}$} & \multirow[b]{2}{*}{$\begin{array}{r}\text { Days to } \\
\text { flower }\end{array}$} \\
\hline & & Root & Shoot & & Root & Shoot & & & & & & \\
\hline$\overline{0}$ & 6.4 & 0.10 & 0.71 & 9.8 & 0.29 & 2.33 & 18.0 & 11.8 & 112 & 19.2 & 10.8 & 132 \\
\hline 3.5 & 5.6 & 0.10 & 0.65 & 8.2 & 0.27 & 2.01 & 19.1 & 9.7 & 131 & 22.4 & 10.7 & 152 \\
\hline 7 & 5.0 & 0.10 & 0.63 & 8.1 & 0.22 & 1.30 & 20.6 & 9.8 & 128 & 22.4 & 10.3 & 153 \\
\hline 11 & 6.0 & 0.09 & 0.58 & 6.8 & 0.20 & 1.16 & 20.0 & 10.0 & 130 & 22.1 & 10.1 & 153 \\
\hline $\begin{array}{l}\text { Trend } \\
\text { analysis }\end{array}$ & Q & NS & L & $\mathrm{L}$ & $\mathrm{L}$ & $\mathrm{L}$ & NS & NS & $\mathrm{L}$ & NS & NS & $\mathrm{L}$ \\
\hline
\end{tabular}

${ }^{2}$ Values are means of 10 observations.

y Nonsignificant (NS), linear (L), or quadratic (Q); significant at $P \leq 0.05$.

Table 3. The influence of copper treatment of plug trays on seedling and flowering plant charactersitics of Petunia 'Ultra White'.

\begin{tabular}{|c|c|c|c|c|c|c|c|c|c|c|c|c|}
\hline \multirow[b]{3}{*}{$\begin{array}{l}\mathrm{Cu} \text { conen } \\
(\%)\end{array}$} & \multicolumn{3}{|c|}{$\begin{array}{l}\text { At transplant } \\
\text { (plugs) }\end{array}$} & \multicolumn{3}{|c|}{$\begin{array}{l}\text { After } 2 \text { weeks } \\
\text { storage (plugs) }\end{array}$} & \multicolumn{3}{|c|}{$\begin{array}{l}\text { At flowering } \\
\text { (in pot) }\end{array}$} & \multicolumn{3}{|c|}{$\begin{array}{l}\text { At flowering (in pot) from } \\
\text { seedlings stored } 2 \text { weeks }\end{array}$} \\
\hline & \multirow[b]{2}{*}{$\begin{array}{c}\mathrm{Ht} \\
(\mathrm{cm})\end{array}$} & \multicolumn{2}{|c|}{ Dry wt $(\mathrm{g})$} & \multirow[b]{2}{*}{$\begin{array}{l}\mathrm{Ht} \\
(\mathrm{cm})\end{array}$} & \multicolumn{2}{|c|}{ Dry wt $(\mathrm{g})$} & \multirow[b]{2}{*}{$\begin{array}{l}\mathrm{Ht} \\
(\mathrm{cm})\end{array}$} & \multirow{2}{*}{$\begin{array}{c}\text { Shoot } \\
\text { dry wt } \\
\text { (g) }\end{array}$} & \multirow[b]{2}{*}{$\begin{array}{l}\text { Days to } \\
\text { flower }\end{array}$} & \multirow[b]{2}{*}{$\begin{array}{c}\mathrm{Ht} \\
(\mathrm{cm})\end{array}$} & \multirow{2}{*}{$\begin{array}{l}\text { Shoot } \\
\text { dry wt } \\
\text { (g) }\end{array}$} & \multirow[b]{2}{*}{$\begin{array}{r}\text { Days to } \\
\text { flower }\end{array}$} \\
\hline & & Root & Shoot & & Root & Shoot & & & & & & \\
\hline 0 & 5.8 & 0.06 & 0.75 & 16.2 & 0.15 & 2.73 & 21.2 & 1.73 & 57 & 23.6 & 1.80 & 69 \\
\hline 3.5 & 3.6 & 0.05 & 0.70 & 12.4 & 0.12 & 2.20 & 21.8 & 2.53 & 60 & 21.2 & 2.27 & 71 \\
\hline 7 & 4.1 & 0.05 & 0.70 & 14.2 & 0.16 & 2.23 & 22.6 & 2.16 & 63 & 24.3 & 1.59 & 71 \\
\hline 11 & 4.2 & 0.04 & 0.78 & 13.4 & 0.12 & 2.21 & 21.7 & 1.90 & 63 & 20.2 & 1.38 & 71 \\
\hline $\begin{array}{l}\text { Trend } \\
\text { analysis }\end{array}$ & $\mathrm{O}$ & NS & NS & $\mathrm{L}$ & NS & $\mathrm{L}$ & NS & $\mathrm{O}$ & NS & NS & $\mathrm{O}$ & NS \\
\hline
\end{tabular}

${ }^{\mathrm{z}}$ Values are means of 10 observations.

y Nonsignificant (Ns), linear (L), or quadratic (Q); significant at $P \leq 0.05$.

fected. In none of the three species studied were the mature heights of flowering plants affected by $\mathrm{Cu}$ treatment, regardless of time of transplant.

Latimer and Baden (1993) found that RDW of 33-day-old tomato (Lycopersicon esculentum L.) was less in containers treated with $7 \% \mathrm{Cu}(\mathrm{OH})_{2}$. In our study, RDW of nonstored seedlings was less in those from $\mathrm{Cu}$ treated trays than from control trays for impatiens only. However, RDW of stored seedlings decreased linearly with increased $\mathrm{Cu}$ concentrations in impatiens and geraniums. This result suggests that the influence of $\mathrm{Cu}$ is related to concentration and time (length of exposure), at least with the concentrations and species tested.

Results varied among taxa and across $\mathrm{Cu}$ treatments with respect to SDW at flowering. In many cases, SDW was statistically less with increased $\mathrm{Cu}$, but the practical effect is of questionable importance. However, SDW was always highest when no $\mathrm{Cu}$ was used, except for petunia. The quadratic trend in SDW, the lack of RDW differences, and the lack of significance of flowering time imply that petunia is less sensitive to $\mathrm{Cu}$ than impatiens or geranium.

Results of this study suggest that the reduction of root spiraling and increased ease of plug removal from $\mathrm{Cu}$-treated trays, particularly plugs held past the optimal transplant time, may result in practical benefits to the bedding plant industry. Although root weight was generally reduced, plant height at time of flowering was not affected. However, the general reduction in root weight, combined with the increase in time to flower due to $\mathrm{Cu}$ treatment, also suggests that the product or the method of application must change before adoption by the plug industry. It may simply be that the lowest concentration tested $(3.5 \%)$ was too high for the sensitive seedling roots encountered in plug production. Concentrations employed were based on research with woody plants, and lower concentrations or more precise application methods may be necessary for seedling or herbaceous material. Precision application has been used in Japan to apply thin $(<0.025 \mathrm{~mm})$ coatings of $\mathrm{Cu}(\mathrm{OH})_{2}$ to decrease the root control effect while retaining favorable shoot growth on vegetable transplants. Similar application equipment is being developed in the United States (M. Crawford, personal communication). Copper-treated plug trays may be beneficial, especially under conditions of plug storage, but additional work must be done on other species and lower $\mathrm{Cu}$ concentrations before commercial adoption can be recommended.

\section{Literature Cited}

Arnold, M.A. and D.K. Struve. 1989. Growing green ash and red oak in $\mathrm{CuCO}_{3}$-treated containers increases root regeneration and shoot growth following transplant. J. Amer. Soc. Hort. Sci. 114:402-406

Arnold, M.A., D.L. Airhart, and W.E. Davis. 1993. Cupric hydroxide-treated containers affect growth and flowering of annual and perennial bedding plants. J. Environ. Hort. 11:106-110.

Burdett, A.N. 1978. Control of root morphogenesis for improved mechanical stability in containergrown lodgepole pine. Can. J. For. Res. 8:483486
Burdett, A.N. and P.A.F. Martin. 1982. Chemical root pruning of coniferous seedlings. HortScience 17:622-624.

Case, N.G. and M.A. Arnold. 1992. Cupric hydroxide-treated containers decrease pot binding of five species of vigorously rooted greenhouse crops. Proc. Southern Nurseryman's Assn. Res. Conf. 37:94-98.

Krieg, R.J. and W.T. Witte. 1993. Efficacy of cupric hydroxide/latex paint formulation for root pruning 41 species of containerized nursery stock. HortScience 28:527. (Abstr.)

Latimer, J.G. and S.A. Baden. 1993. Spin Out ${ }^{\mathrm{TM}}$ enhances subsequent growth of tomato, but not pepper, transplants. Proc. Southern Nurseryman's Assn. Res. Conf. 38:121-123.

McDonald, S.E., R.W. Tinus, and C.P.P. Reid. 1984 Effect of $\mathrm{CuCO}_{3}$ container wall treatment and mycorrhizae fungi inoculation of growing medium on pine seedling growth and root development. J. Environ. Hort. 2:5-8.

Ruehle, J.L. 1985. The effect of cupric carbonate on root morphology of containerized mycorrhizal pine seedlings. Can. J. For. Res. 15:586-592.

Ruter, J.M. 1994. Evaluation of control strategies for reducing rooting-out problems in pot-inpot production systems. J. Environ. Hort. 12:5154.

Stinson, R.F. and C.G. Keyes. 1953. Preliminary report on copper and zinc napthenate treatments to control algae growth on clay flower pots. Proc. Amer. Soc. Hort. Sci. 61:569-572.

Struve, D.K., M.A. Arnold, and D.H. Chinery. 1987. Red oak whip production in containers. Proc. Intl. Plant Prop. Soc. 34:415-420.

Struve, D.K. and T. Rhodus. 1990. Turning copper into gold. Amer. Nurseryman 172:114-125.

Svenson, S.E. and D.I. Johnson. 1992. Faster growth of Radermachera sinica after transplanting from copper-treated liners. Proc. Southern Nurseryman's Res. Conf. 37:100-101. 